\title{
Pengaruh Disiplin Kerja Terhadap Kinerja Pegawai Kantor Pelayanan Pajak
}

\author{
${ }^{1}$ Heri Dirgantara, ${ }^{2}$ Anton Parlindungan Sinaga, ${ }^{3}$ Indra Suprasa, ${ }^{4}$ Oki Doni Siregar \\ ${ }^{1-4}$ Program Magister Manajemen,Fakultas Ekonomi,Universitas Islam Sumatera Utara
}

\author{
Article history \\ Received: 18 Nov 2020 \\ Revised: 13 Dec 2020 \\ Accepted: 03 Jan 2021 \\ *Corresponding Author: \\ Heri Dirgantara, Program \\ Studi Magister Manajemen, \\ Fakultas Ekonomi, \\ Universitas Islam Sumatera \\ Utara \\ Email: \\ heridirgantara@gmail.com
}

\begin{abstract}
Abstrak: Disiplin kerja menjadi kesadaran dan kesediaan seseorang mentaati semua peraturan organisasi dan norma-norma sosial yang berlaku. Adapun masalah penelitian yaitu pengaruh disiplin kerja terhadap kinerja pegawai kantor pelayanan pajak pratama medan barat. Adapun tujuan dari penelitian ini yaitu untuk mengetahui pengaruh disiplin kerja terhadap kinerja pegawai kantor pelayanan pajak pratama medan barat. Metode pengumpulan data yang digunakanadalah dengan pendekatan survey melalui observasi, wawancara, pembagian kuesioner dan studi dokumentasi. Metode analisis data yang digunakan adalah analisis regresi linier berganda. Populasi penelitian ini semua pegawai Kantor Pelayanan Pajak Pratama Medan Barat yang berjumlah 104 orang. Hasil penelitian ini menunjukan bahwa variabel disiplin kerja memiliki nilai p-value (pada kolom Sig.) 0,008 $<0,05$ artinya signifikan, sedangkan $t$ hitung 2,791 > dari t tabel 2,012 artinya signifikan. Hal ini berarti bahwa disiplin kerja berpengaruh terhadap kinerja pegawai.

Kata Kunci : Pengaruh, Disiplin kerja, Kinerja pegawai, Pelayanan Pajak
\end{abstract}

\section{PENDAHULUAN}

Penting untuk memberi perhatian yang besar kepada pegawai yang memiliki watak dan sifat yang berbeda serta tujuan yang berbeda. Sehingga masalah pegawai tidak mudah untuk diperhitungkan. Meskipun pegawai telah dimotivasi, fasilitas kerja sudah cukup tersedia, akan tetapi disiplin pegawai juga sangat penting. Seorang pemimpin dalam suatu organisasi lembaga pemerintahan harus mampu menegakkan kedisiplinan terhadap para pegawai (Husein, 2009). Karena dengan disiplin, maka kesadaran dan kesediaan seseorang mentaati semua peraturan organisasi dan norma-norma sosial yang berlaku yang dapat ditinjau dari indikator-indikator kedisiplinan seperti tujuan dan kemampuan, teladan pimpinan, balas jasa, keadilan, pengawasan melekat, sanksi hukuman, ketegasan dan hubungan kemanusiaan dapat tercapai (Sedarmayanti, 2009). Tujuan dari disiplin adalah untuk menghindari adanya kelainan serta kecerobohan dalam melaksanakan tugas yang dilimpahkan kepada para pegawainya.

Disiplin merupakan fungsi operatif manajemen pegawai yang terpenting karena semakin baik disiplin pegawai maka semakin tingi produktivitas kerja yang dapat dicapainya. Tanpa disiplin yang baik dari pegawai, sulit bagi organisasi mencapai hasil yang optimal (Ruky, 2009). Pada umumnya apabila orang mendengar perkataan disiplin, maka orang tersebut cenderung mendefinisikannya dalam pengertian yang sempit dan bersifat menghukum (Sinungan, 2010). Beberapa Cara untuk Menegakkan Disiplin pada suatu organisasi (Hary, 2008) yakni keteladanan pimpinan, ketegasan, ancaman, dan kesejahtraan. Untuk menerapkan displin kerja pada pegawai, maka mereka memerlukan suatu pembinaan yang diantaranya sebagai berikut (Jakson, 2008) :

1. Menepati segala peraturan dan kebijakan ketenagakerjaan maupun peraturan dan kebijakan organisasi yang berlaku, baik tertulis maupun tidak tertulis, serta melaksanakan perintah manajemen. 
2. Dapat melaksanakan pekerjaan dengan sebaik-baiknya serta mampu memberikan pelayanan yang maksimum kepada pihak tertentu yang berkepentingan dengan organisasi sesuai dengan bidang pekerjaan yang diberikan kepadanya.

3. Dapat menggunakan dan memelihara sarana dan prasarana, barang dan jasa organisasi dengan sebaik-baiknya.

4. Dapat bertindak dan berprilaku sesuai dengan norma-norma yang berlaku pada perusahaan.

5. Tenaga kerja mampu menghasilkan produktivitas yang tinggi sesuai dengan harapan perusahaan, baik dalam jangka pendek maupun jangka panjang.

Sesuai dengan penjelasan displin kerja, maka disini penelitian mengungkapkan kasus yang sama terkait sikap kedisplinan di kantor pajak Pratama Medan. Peneliti tertarik untuk mengungkapkan pengaruh kedisplinan pegawai terhadap kinerja pegawai di kantor tersebut. Sehingga nantinya akan dapat dijelaskan sberapa besar pengaruhnya tersebut.

\section{METODOLOGI PENELITIAN}

Adapun metode pengumpulan data yang digunakan peneliti dengan pendekatan survey melalui observasi, wawancara, pembagian kuesioner dan studi dokumentasi. Metode analisis data yang digunakan adalah analisis regresi linier berganda. Populasi penelitian ini semua pegawai Kantor Pelayanan Pajak Pratama Medan Barat yang berjumlah 104 orang. Penelitian ini dilakukan di Kantor Pelayanan Pajak Pratama Medan Barat Jalan Asrama No 7-A Me.

\section{Sampel}

Populasi yang terdapat dalam penelitian ini berjumlah 104 dan presisi yang ditetapkan atau tingkat signifikansi 0,1, maka besarnya sampel pada penelitian ini adalah :

$$
\begin{aligned}
\mathrm{n} & =\frac{104}{1150,1^{2}+1} \\
& =51 \text { orang }
\end{aligned}
$$

\section{Teknik Pengumpulan Data}

Data dalam penelitian ini terdiri dari data primer dan data sekunder.

\section{a. Validitas}

Untuk pengujian ini dilakukan dengan menggunakan koefisien koraelasi Product Moment dengan rumus:

$$
r_{x y}=\frac{n \sum_{h=1}^{n} X Y-\sum_{h=1}^{n} X \sum_{h=1}^{n} Y}{\sqrt{\left\{n \sum_{h=1}^{n} X^{2}-\left(\sum_{h=1}^{n} X\right)^{2}\right\}\left\{n \sum_{h=1}^{n} Y^{2}-\left(\sum_{h=1}^{n} Y\right)^{2}\right\}}}
$$

Nilai koefisien korelasi masing-masing item terhadap total masing-masing item ( $\mathrm{r}$ hitung ) dibandingkan dengan $r$ tabel. Item dikatakan valid jika nilai $r$ hitung $>r$ tabel.

\section{b. Reliabilitas}

Untuk pengujian ini dilakukan dengan teknik Cronbach's Alpha. Untuk memudahkan perhitungan validitas dan reliabilitas dapat dilaklukan dengan program Statistical Product and Service Solution (SPSS). 


\section{Teknik Analisis Data}

Data yang sudah dikumpulkan akan dianalisis, analisis yang digunakan adalah model Regresi Linier berganda dengan persamaan :

$$
\hat{\mathrm{Y}}=\mathrm{b}_{0}+\mathrm{b}_{3} \mathrm{X}_{3}
$$

Dimana :

$$
\begin{aligned}
& \hat{\mathrm{Y}}=\text { Kinerja Pegawai } \\
& \mathrm{b}_{0}=\text { Konstanta } \\
& \mathrm{b}_{3}=\text { Koefisien variabel disiplin kerja } \\
& \mathrm{X}_{3}=\text { Disiplin Kerja }
\end{aligned}
$$

Untuk menguji hipotesis digunakan uji F dengan rumus :

$$
F_{h i t}=\frac{J K_{r e g} / k}{J K_{r e s} /(n-k-1)}
$$

Dimana :

$\mathrm{JK}_{\text {reg }}=$ Jumlah kuadrat regresi

$\mathrm{JK}_{\text {reg }}=$ Jumlah kuadrat residu

$\mathrm{n} \quad=$ Jumlah Sampel

$\mathrm{K}=$ Jumlah varians

Jika : F hitung > F tabel : Hipotesis diterima dan apabila $\mathrm{F}$ hitung < F tabel : Hipotesis ditolak.

Penelitian ini menggunakan tingkat kepercayaan $95 \%(\alpha=0.05)$ dan untuk memudahkan penulis dalam pengolahan data digunakan Program SPSS VA. 12.00,Selanjutnya untuk mengetahui besar pengaruh variabel bebas terhadap variabel terikat digunakan Uji koefisien Determinasi (D) dengan rumus sebagai berikut:

$$
\mathrm{D}=\mathrm{r}^{2} \mathrm{X} 100 \%
$$

\section{HASIL DAN PEMBAHASAN}

\section{Statistik Deskriptif}

Tabel 1. Statistik Deskriptif

\begin{tabular}{llcccccc}
\hline \multirow{2}{*}{ Instrumen } & \multicolumn{6}{c}{ Frekwensi (Persentase) } \\
\cline { 2 - 7 } & & $\mathbf{5}$ & $\mathbf{4}$ & $\mathbf{3}$ & $\mathbf{2}$ & $\mathbf{1}$ & Total \\
\hline 1. & KP1 & 29,4 & 58,8 & 5,9 & 3,9 & 2,0 & 100 \\
2. & KP2 & 41,2 & 58,8 & 0 & 0 & 0 & 100 \\
3. & KP3 & 45,1 & 51,0 & 3,9 & 0 & 0 & 100 \\
4. & KP4 & 29,4 & 58,8 & 7,8 & 2,0 & 2,0 & 100 \\
5. & KP5 & 52,9 & 39,2 & 2,0 & 5,9 & 0 & 100 \\
6. & KP6 & 45,1 & 54,9 & 0 & 0 & 0 & 100 \\
7. & KP7 & 29,4 & 45,1 & 25,5 & 0 & 0 & 100 \\
8. & KP8 & 17,6 & 68,6 & 13,7 & 0 & 0 & 100 \\
\hline
\end{tabular}




\begin{tabular}{lllllllll}
\hline 9. & KP9 & 21,6 & 72,5 & 5,9 & 0 & 0 & 100 \\
10. & KP10 & 17,6 & 64,7 & 15,7 & 2,0 & 0 & 100 \\
\hline 1. & DK1 & 33,3 & 64,7 & 2,0 & 0 & 0 & 100 \\
2. & DK2 & 39,2 & 58,8 & 2,0 & 0 & 0 & 100 \\
3. & DK3 & 25,5 & 60,8 & 13,7 & 0 & 0 & 100 \\
4. & DK4 & 33,3 & 64,7 & 2,0 & 0 & 0 & 100 \\
5. & DK5 & 49,0 & 45,1 & 5,9 & 0 & 0 & 100 \\
6. & DK6 & 25,5 & 62,7 & 11,8 & 0 & 0 & 100 \\
7. & DK7 & 41,2 & 56,9 & 2,0 & 0 & 0 & 100 \\
8. & DK8 & 35,3 & 43,1 & 21,6 & 0 & 0 & 100 \\
9. & DK9 & 39,2 & 56,9 & 3,9 & 0 & 0 & 100 \\
10. & DK10 & 25,5 & 62,7 & 11,8 & 0 & 0 & 100 \\
\hline
\end{tabular}

\section{Uji Kualitas Data}

Tabel 2. Uji Validitas Variabel

\begin{tabular}{|c|c|c|c|c|c|}
\hline \multirow[t]{2}{*}{ Variabel } & \multicolumn{2}{|c|}{ Instrumen } & \multirow{2}{*}{$\begin{array}{c}\text { r-hitung } \\
0.605\end{array}$} & \multirow{2}{*}{$\begin{array}{r}\text { r-tabel } \\
0.275\end{array}$} & \multirow{2}{*}{$\frac{\text { Keterangan }}{\text { Valid }}$} \\
\hline & 1) & DK1 & & & \\
\hline \multirow{9}{*}{$\begin{array}{l}\text { Disiplin Kerja } \\
\text { (X3) }\end{array}$} & 2) & DK2 & 0.753 & 0.275 & Valid \\
\hline & 3) & DK3 & 0.700 & 0.275 & Valid \\
\hline & 4) & DK4 & 0.708 & 0.275 & Valid \\
\hline & 5) & DK5 & 0.686 & 0.275 & Valid \\
\hline & 6) & DK6 & 0.569 & 0.275 & Valid \\
\hline & 7) & DK7 & 0.572 & 0.275 & Valid \\
\hline & 8) & DK8 & 0.576 & 0.275 & Valid \\
\hline & 9) & DK9 & 0.717 & 0.275 & Valid \\
\hline & 10) & DK10 & 0.683 & 0.275 & Valid \\
\hline \multirow{10}{*}{$\begin{array}{l}\text { Kinerja } \\
\text { Pegawai (Y) }\end{array}$} & 1) & KP1 & 0.349 & 0.275 & Valid \\
\hline & 2) & KP2 & 0.651 & 0.275 & Valid \\
\hline & 3) & KP3 & 0.484 & 0.275 & Valid \\
\hline & 4) & KP4 & 0.637 & 0.275 & Valid \\
\hline & 5) & KP5 & 0.665 & 0.275 & Valid \\
\hline & 6) & KP6 & 0.600 & 0.275 & Valid \\
\hline & 7) & KP7 & 0.705 & 0.275 & Valid \\
\hline & 8) & KP8 & 0.683 & 0.275 & Valid \\
\hline & 9) & KP9 & 0.530 & 0.275 & Valid \\
\hline & 10) & KP10 & 0.646 & 0.275 & Valid \\
\hline
\end{tabular}




\section{Reliabilitas}

Tabel 3. Uji Reliabilitas Variabel

\begin{tabular}{lccc}
\hline \multicolumn{1}{c}{ Variabel } & $\begin{array}{c}\text { Cronbach's } \\
\text { Alpha }\end{array}$ & $\begin{array}{c}\text { Batas } \\
\text { Reliabilitas }\end{array}$ & Keterangan \\
\hline Disiplin Kerja (X3) & 0.760 & 0.6 & Reliabel \\
Kinerja Pegawai & 0.744 & 0.6 & Reliabel
\end{tabular}

(Y)

Dari data tabel di atas dapat dilihat bahwa hasil perhitungan uji reliabilitas menunjukkan alpha cronbach's pada masing-masing kolom variabel tersebut lebih besar dari 0,6 (batas reliabilitas) maka dapat dinyatakan instrumen tersebut reliabel.

\section{Pengujian Hipotesis}

Tabel 4. Pengujian Hipotesis dengan Uji t

\begin{tabular}{llr|r|r|r|r}
\multicolumn{2}{c}{ Model } & \multicolumn{2}{c|}{ Unstandardized Coefficients } & & \\
\hline 1 & B & Std. Error & Beta & t & Sig. \\
\hline & (Constant) & 4.349 & 3.394 & & 1.281 & .206 \\
\cline { 2 - 9 } & Disiplin Kerja & .339 & .121 & .337 & 2.791 & .008
\end{tabular}

Berdasarkan tabel di atas, diketahui nilai $t$ hitung dari masing-masing variabel independen secara parsial berpengaruh terhadap variabel dependen yaitu Variabel disiplin kerja memiliki nilai $p$-value (pada kolom Sig.) 0,008 < 0,05 artinya signifikan, sedangkan t hitung 2,791 > dari t tabel 2,012 artinya signifikan. Hal ini berarti bahwa disiplin kerja berpengaruh terhadap kinerja pegawai.

\section{Pengujian Hipotesis dengan Uji F}

Tabel 5. Hasil Uji Simultan (Uji F)

\begin{tabular}{|c|c|c|c|c|c|c|}
\hline \multicolumn{7}{|c|}{ ANOVA $^{a}$} \\
\hline M & & $\begin{array}{l}\text { Sum of } \\
\text { Squares }\end{array}$ & $\mathrm{df}$ & Mean Square & $\mathrm{F}$ & Sig. \\
\hline \multirow[t]{3}{*}{1} & Regression & 556.740 & 3 & 185.580 & 49.623 & $.000^{\mathrm{b}}$ \\
\hline & Residual & 175.769 & 47 & 3.740 & & \\
\hline & Total & 732.510 & 50 & & & \\
\hline
\end{tabular}

Berdasarkan uji $\mathrm{F}$ atau uji Anova atau uji simultan di atas diperoleh $\mathrm{F}$ hitung sebesar 49,623 pada $\alpha=5 \%$ atau 0,05 dengan tingkat signifikan 0,000 karena nilai probabilitas $(0,000)$ jauh lebih kecil dari 0,05 maka model regresi dapat dipakai untuk memprediksi bahwa disiplin kerja (X3) sebagai variabel independen secara bersama-sama (simultan) berpengaruh terhadap kinerja pegawai (Y). Dengan kata lain disiplin kerja (X3) secara simultan mempunyai pengaruh yang positif dan signifikan terhadap kinerja pegawai, karena $\mathrm{F}$ hitung > F tabel yakni 49,623 > 2,80. Hal tersebut berarti jika disiplin kerja (X3) diterapkan 
di dalam organisasi maka akan berdampak pada kenaikan kinerja pegawai (Y), sebaliknya jika disiplin kerja (X3) tidak diterapkan maka akan berdampak pada penurunan kinerja pegawai (Y).

\section{Analisis Koefisien Determinasi $\left(\boldsymbol{R}^{2}\right)$}

Tabel 6. Hasil Analisis Koefisien Determinasi

\begin{tabular}{ll|r|r|r} 
& \multicolumn{4}{c}{ Model Summary } \\
Model & R & R Square & R Square & \multicolumn{1}{c}{$\begin{array}{c}\text { Std. Error of the } \\
\text { Estimate }\end{array}$} \\
\hline 1 & $.872^{\mathrm{a}}$ & .760 & .745 & 1.934
\end{tabular}

Hasil olahan pada tabel di atas terlihat nilai koefisien determinasi $\left(R^{2}\right)$ yang sudah disesuaikan (Adjusted $R$ Square) sebesar 0,745. Artinya 74,5\% variabel dependen (kinerja pegawai) dipengaruhi atau dijelaskan oleh variabel independen yaitu disiplin kerja dan sisanya sebesar 25,5\% (100\% - 74,5\%) dipengaruhi atau dijelaskan oleh variabel lain di luar variabel yang digunakan dalam penelitian ini.

\section{Hasil Persamaan Regresi}

Persamaan regresi yang telah dirumuskan dilakukan pengolahan data sehingga didapat persamaan akhir yaitu :

$$
\mathrm{Y}=4,349+0,339 \mathrm{X}_{3}
$$

Pada model regresi ini, nilai konstanta yang tercantum sebesar 4,349 dapat diartikan jika variabel bebas dalam model diasumsikan sama dengan nol atau variabel bebas dalam hal ini motivasi kerja, fasilitas kerja dan disiplin kerja diterapkan, maka kinerja pegawai akan mengalami kenaikan sebesar 4,349 satuan.

Nilai besaran koefisien regresi $\beta_{3}$ sebesar 0,339 pada penelitian ini dapat diartikan bahwa variabel disiplin kerja (X3) berpengaruh positif terhadap kinerja pegawai $(Y)$. Hal ini menunjukkan bahwa ketika variabel disiplin kerja terpenuhi, maka kinerja pegawai akan naik 0,251 satuan.

\section{Pengaruh Disiplin Kerja Terhadap Kinerja Pegawai}

Secara parsial hasil penelitian ini menunjukan bahwa disiplin kerja berpengaruh positif dan signifikan terhadap kinerja pegawai di Kantor Pelayanan Pajak Pratama Medan Barat. Pengaruh positif menunjukkan bahwa pengaruh disiplin kerja adalah searah dengan kinerja pegawai atau dengan kata lain adanya loyalitas kerja yang baik akan berpengaruh terhadap kinerja pegawai yang baik/tinggi, demikian sebaliknya bila disiplin kerja yang baik tersebut tidak terpenuhi, maka kinerja pegawai akan rendah/buruk. Pengaruh signifikan menunjukkan bahwa disiplin kerja mempunyai peranan yang penting dalam meningkatkan kinerja pegawai di Kantor Pelayanan Pajak Pratama Medan Barat.

Hal ini terbukti dari jawaban responden yang rata-rata setuju bahwa Pimpinan sering memberikan dorongan kepada bawahan untuk melakukan pekerjaan sesuai petunjuk, Pimpinan sering memberi kesempatan kepada pegawai untuk mengikuti pendidikan dan pelatihan, Kepemimpinan atasan memberi teladan untuk penerapan disiplin, Pimpinan sangat 
memperhatikan kesejahteraan pegawai, paling tidak suka meninggalkan tugas, selalu menyelesaikan tugas sesuai petunjuk yang diberikan, Bila atasan sering memberi petunjuk bawahan menerima dengan senang hati, selalu mematuhi semua peraturan yang dibuat pimpinan, selalu masuk kerja tepat pada waktunya, Pegawai selalu diberi sanksi bila tidak disiplin.

\section{KESIMPULAN}

Sesuai hasil analisis penelitian maka dapat diamil kesimpulan sesuai tujuan penelitian yang dikemukakan:

1. Disiplin kerja berpengaruh positif dan signifikan terhadap kinerja pegawai Kantor Pelayanan Pajak Pratama Medan Barat, hal ini didukung analisis t hitung > t-tabel $(1,347<2,012)$ pada $\mathrm{n}=51$ dengan taraf sifgnifikan $95 \%$.

2. Nilai F-hitung > F tabel $(49,623>2,80)$ hal ini menyatakan bahwa terdapat pengaruh positif dan signifikan disiplin kerja terhadap kinerja pegawai Kantor Pelayanan Pajak Pratama Medan Kota. Dengan demikian hipotesis yang diajukan diterima kebenarannya.

\section{DAFTAR PUSTAKA}

Hary Kusnadi. 2008. Manajemen Sumber Daya Manusia, Jakarta: Ghalia Indonesia.

Husein. 2009. Ensiklopedia Manajemen. Jakarta: Balai Pustaka

Jakson, Jhom H. 2008. Manajemen Sumber Daya Manusia. Jakarta: Salemba Empat

Ruky. 2009. Manajemen Personalia. Yogyakarta: BPFE

Sedarmayanti. 2009. Sumberdaya Manusia dan Produktivitas Kerja. Bandung: Ilham Jaya

Sinungan Muchdarsyah. 2010. Produktivitas Apa dan Bagaimana. Jakarta : Bumi Aksara. 